\title{
Multiple myeloma mimicking metastatic lung cancer
}

\author{
Metastatik akciğer kanserini taklit eden multipl miyelom
}

\author{
Yavuz FURUNCUOĞLU, ${ }^{1}$ Yalçın ÇıRAK, ${ }^{2}$ Hacı Mehmet TÜRK, ${ }^{3}$ Melih BAŞAR, ${ }^{4}$ \\ Hülya ORTAPAMUK, ${ }^{5}$ Ahmet Cemil KAUR ${ }^{6}$ \\ 'Department of Internal Medicine, Bahçeşehir University Faculty of Medicine, İstanbul \\ ${ }^{2}$ Department of Oncology, Bahçeşehir University Faculty of Medicine, Istanbul \\ ${ }^{3}$ Department of Oncology, Bezmi Alem University Faculty of Medicine, İstanbul \\ ${ }^{4}$ Department of Internal Medicine, Göztepe Medical Park Hospital, Istanbul \\ ${ }^{5}$ Department of Nuclear Medicine, Bahçeşehir University Faculty of Medicine, Istanbul \\ ${ }^{6}$ Private Pathology Laboratory, Istanbul
}

\begin{abstract}
Multiple myeloma is a hematological malignancy characterized by a clonal proliferation of plasma cells in the bone marrow. Extramedullary dissemination of multiple myeloma is uncommon. Only in rare cases, the malignant plasma cells of multiple myeloma had infiltrated the lung parenchyma. In this case report, we presented a case of multiple myeloma with lung plasmacytoma, in a 42-year-old patient, hospitalized for pain and infiltrative mass in the right lung. The results of his initial evaluation with computed tomography and positron emission tomograpy scanning, resembled lung tumor with bone metastasis. Surprisingly, biopsies from lung tumor and bone metastasis, revealed malignant plasma cells. We found $\mathrm{M}$ spike in protein electrophoresis and lambda monoclonal band in immune electrophoresis. A bone marrow biopsy evaluation was done and justified multiple myeloma diagnosis before hematology referral. Multiple myeloma diagnosis at the age of 42 is quite rare.
\end{abstract}

Keywords: Cancer; lung; metastasis; myeloma.
Multipl miyelom kemik iliğinde plasma hücrelerinin klonal proliferasyonu ile karekterize hematolojik malign bir hastalıktır. Multipl miyelomda ekstramedüller yayılım sık değildir. Çok nadir olgularda multipl miyelom nedenli plazma hücreleri akciğer parankimini infiltre eder. Bu yazıda, sağ akciğerde infiltratif kitle ve ağrı nedeniyle hastaneye yatırılan, akciğer plasmasitomlu multipl miyelomu olan 42 yaşında bir hasta sunuldu. Bilgisayarlı tomografi ve pozitron emisyon tomografisi ile yapılan ilk değerlendirmede kemik metastası olan akciğer tümörüne benzetildi. Akciğerdeki tümörden ve kemikteki metastastan yapılan biyopside sürpriz olarak malign plazma hücreleri görüldü. Protein elektroforezinde $M$ spike ve immün elektroforezde monoklonal lamda bandı bulundu. Kemik iliği biyopsisi yapıldı ve multipl miyelom tanısı konarak hematolojiye refere edildi. Multipl miyelom 42 yaşında nadir görülür.

Anahtar sözcükler: Kanser; akciğer; metastaz; myelom.
Multiple myeloma (MM) is a hematological malignancy characterized by a clonal proliferation of plasma cells in the bone marrow. It is a common disease, which is accounting for about $10 \%$ of all hematologic malignancies in the United States.

Extramedullary dissemination of multiple myeloma is uncommon. Only in rare cases, the malig- nant plasma cells of multiple myeloma had infiltrated the lung parenchyma.

\section{CASE REPORT}

A 42-year-old male patient presented in our outpatient clinic with the complaint of right sided chest pain. There were no weight loss, fever, sweating or cough. He smoked cigarettes 70 packs/year.

Presented at the Istanbul University Internal Medicine Days (2013, Sapanca, Turkey).

Correspondence (illetişim): Dr. Yavuz FURUNCUOĞLU. Bahçeşehir Üniversitesi Tıp Fakültesi, İç Hastalıkları Anabilim Dalı, İstanbul, Turkey. Tel: +90 - 216 - 4684444 e-mail (e-posta): dryavuzf@yahoo.com 
On his physical examination; his blood pressure was $130 / 80 \mathrm{mmHg}$, heart and lung sounds were normal. Thre were no prominent lenf node enlargements. Also there were no significant pathological findings in abdominal examination. There was no visible mass in his chest wall. His medical history was also insignificant. Results of his routine blood tests were as follows:

$\mathrm{Hb}, 14.2 \mathrm{~g} / \mathrm{dL}$; platelet count, 228x109/L; and white blood cell (WBC), 13.6x109/L (segmented neutrophil, 51.3\%; lymphocyte, $35.8 \%$; monocyte, 8.9\%; and eosinophil, 3.09\%); ESR: $83 \mathrm{~mm} / \mathrm{h}$ CRP: $149 \mathrm{mg} / \mathrm{L}$ (normal range <8.2); Creatinine, $0.95 \mathrm{mg} / \mathrm{dL}$ (reference range, 0.6-1.2 g/dL); Lactate dehydrogenase, $254 \mathrm{U} / \mathrm{L}$ (reference range, 125-243 U/L). AST-ALT, ALP were normal.

Computed tomography (CT) (GE Hangwei medical system Co. Beijing P.R.China) examination of the chest revealed a right lung mass with sternal and vertebral metastases (Fig. 1).

This mass was a lobulated tumour, located at the anteriobasalis of the right lung upper lobe with a dimension of $97 \times 65 \mathrm{~mm}$ in diameter. It had been extended anteriorly to pectoralis muscle margin, destructing $3^{\text {rd }}$ and $4^{\text {th }}$ ribs. It had manibrium sterni metastasis of $4 \times 4.5 \mathrm{~cm}$ in diameter and a lytic mass in T11 vertebrae.

A consecutive Positron emission tomography imaging with flurodeoxyglucose (FDG PET/CT)

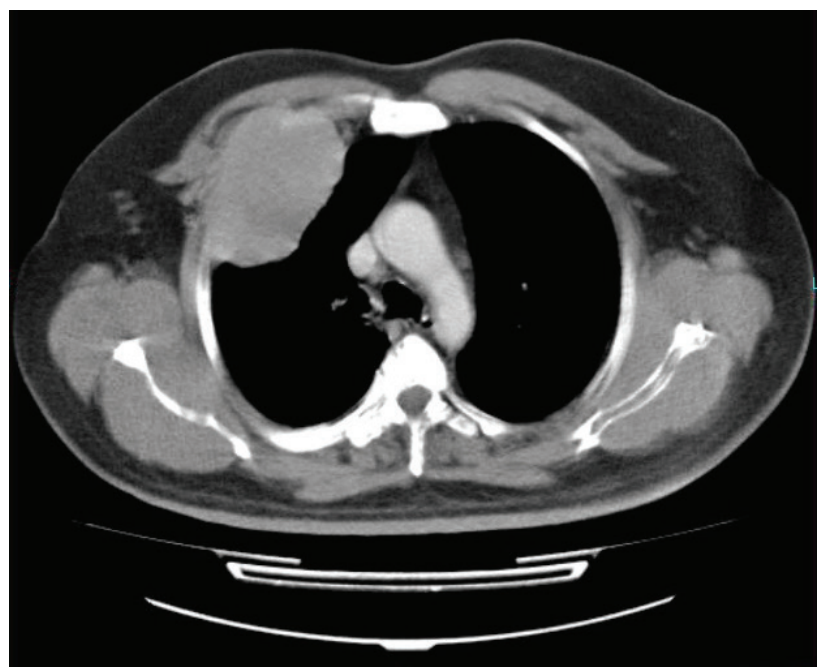

Fig. 1. Right lung mass at initial CT.
(Siemens biograph 2 LSO Germany) was performed. It also showed a malignant hyper metabolic mass of 95x60 in diameter (SUV max: 12.7), located at the anteriobasalis of the right lung upper lobe which had been extended anteriorly to pectoralis muscle margin, destructing $3^{\text {rd }}$ and $4^{\text {th }}$ ribs. It also revealed hypermetabolic destructive bone lesions at manibrium sterni (SUV max: 8.0), right humerus shaft (SUV max: 15.0), T11 (SUV max: 5.9) and L4 vertebrae (SUV max: 6.4). There were partly hypermetabolic, mostly sclerotic and ametabolic widespread skeletal areas of malignant lesions. There were bilateral pleural effusions mainly considered as malignant and mediastinal reactive lymp nodes. Also there were hypermetabolic lymph nodes at L4 vertebrae level which were considered as metastasis (Fig. 2).

CT guided multiple biopsies were taken from the lung mass and the metastatic lesion of vertebrae.

Tru-cut biopsy of right lung mass, Malignant tumour with plama cells (Plasma cell myeloma) (Fig. 3a) and biopsy from L4 vertebrae showed

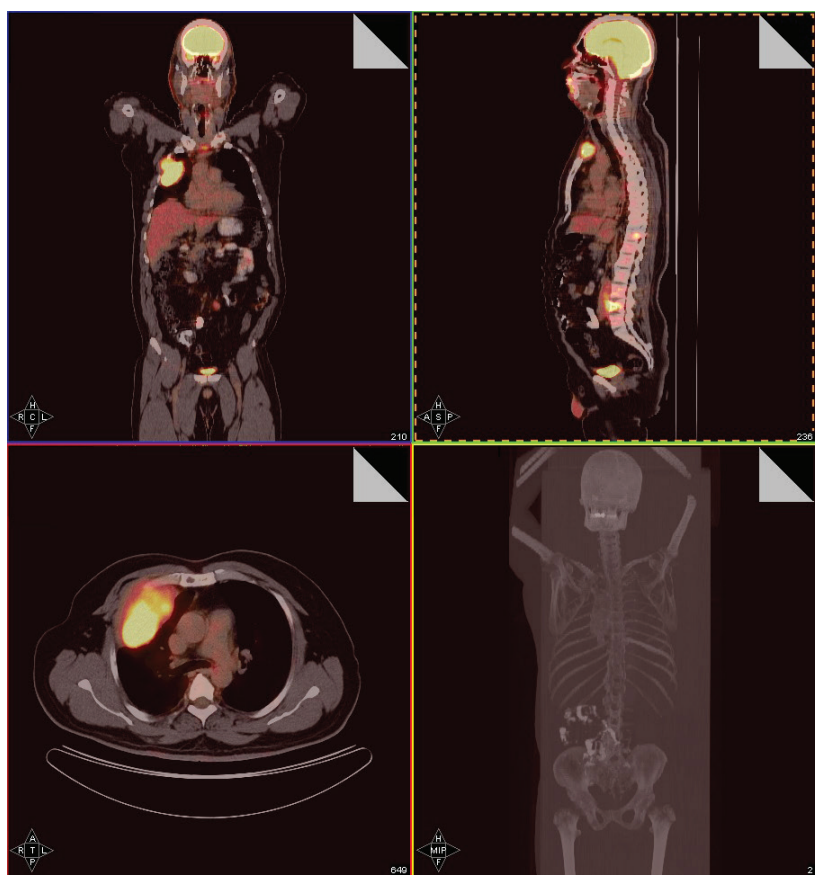

Fig. 2. PET/CT showing the malignant hyper metabolic mass at the anteriobasalis of the right lung upper lobe with hypermetabolic destructive bone lesions at manibrium sterni, right humerus shaft, T11 and L4 vertebrae. 

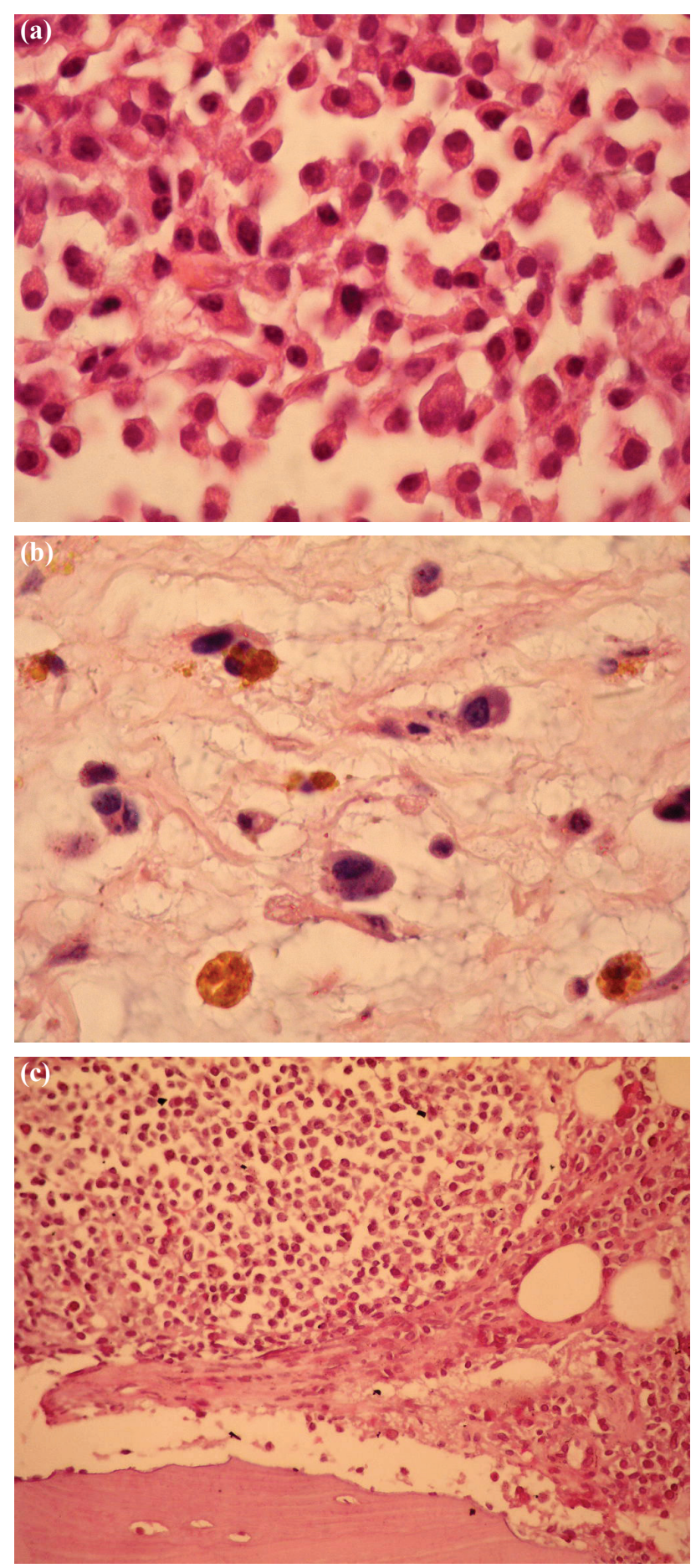

Fig. 3. (a) Biopsy from right lung mass: $x 400$ magnification, H\&E dye Diffuse tumoral infiltration, showing plasmocytoid cellular morphology. (b) Lomber vertebrae biopsy: X1000 magnification, H\&E dye Atypical tumoral cell infiltration showing plasmocytoid morpholgy in fibrohyaline tissue. (c) Bone marrow biopsy: Showing plasma cells infiltrating $90 \%$ of bone marrow space. degenarated bone trabeculea with atypical plasma cells (Fig. 3b).

Right after the surprising results of the pathological evaluation, protein and immune electrophoresis were done. Their results were as follows;

Total protein: 5.3 (reference range, 6.4-8.3 g/ $\mathrm{dL}$ ); Albumin, $2.52 \mathrm{~g} / \mathrm{dL}$ (reference range, 3.5-5.2 g/dL); Alfa 1. 4.65\% (2.2-4.6) Alfa 2: $22.79 \%$ (8.2-12.5) Beta 1:9.8\% (7.2-14.2) Gamma: 15.2\% (11.5-18.6) M spike: 2.94 g IgA: 11.2 (40-350), IgG: 390 (650-1600), IgM: 11 (50-300), kappa light chain: 66 (170-370) and lambda was measured at to $424 \mathrm{mg} / \mathrm{dl}$ (reference range, $90-210 \mathrm{mg}$ / dl).

In the gel electrophoresis revealed a monoclonal band in lambda antisera and lambda FLC was measured at to $424 \mathrm{mg} / \mathrm{dl}$ (reference range, 90-210 $\mathrm{mg} / \mathrm{dl})$.

Results were consistent with multipl myeloma, so a bone marrow biops was performed.

The result of bone marrow biopsy showed CD38, CD56 and lambda positive, kappa negative plasma cells infiltrating $90 \%$ of bone marrow space. Conclusion was plasma cell myeloma showing monoclone of lambda light chain (Fig. 3c).

Based on these results, the patient was diagnosed as multipl myeloma with extramedullary dissemination, primarly into the lung.

The patient was referred to the hematology department for chemotherapy. After treatment bone marrow biopsy revealed total cure. Patient's follow up is still going on in hematology outpatient clinic.

Multiple myeloma is rare in young population. Plasmacytoma resembling metatstatic lung cancer in the young is very rare. In that manner, we decided to present this case.

\section{DISCUSSION}

Plasma cell myeloma (PCM) is a malignant hematologic disease characterized by the proliferation of neoplastic plasma cells, producing excessive amounts of monoclonal immunoglobulin (Ig) 
or light chain. ${ }^{[1,2]}$

Although plasma cells are widely distributed throughout the body, PCM is found most often within the bone and bone marrow (BM), while the dissemination of extramedullary plasmacytoma into the lung has been reported to be very rare. ${ }^{[3]}$

MM establishes $27 \%$ of all biopsied bone tumors, and $1 \%$ of all malignancies. ${ }^{[4,5]}$ It is seen typically between ages 50 to 70 and it is rare before the age of $40 .{ }^{[4]}$ It is seen twice as much in men then in women.

Classically, PCM occurs mainly in BM-rich bone. ${ }^{[6]}$ Therefore, primary clinical presentation includes bone pain, and anemia. ${ }^{[7,8]}$

Extramedullary plasmacytomas have been reported in $15-20 \%$ of patients at diagnosis and in an additional $15 \%$ during the course of PCM, and these patients are often associated with highrisk diseases like myelomatous pleural effusion (MPE). ${ }^{[9]}$

Extramedullary existence of plasmacytoma is not common and the incidence of thoracic cases is low, especially in patients presenting with pulmonary plasmacytoma and malign pleural efusion to simulate a pleural mesothelioma or lung cancer. ${ }^{[6,10]}$

We report here a unique presentation of PCM to include monoclonal components and lung plasmacytoma as initially mistaken for metastatic lung cancer.

In this case, a precise diagnosis of PCM is difficult when only clinical and imaging studies are conducted. In order to discriminate extramedullary PCM from other malignancies, biochemical assays such as electrophoresis are very helpful to confirm the presence of monoclonal components when performed along with pathologic examinations of the mass and bone marrow.

\section{REFERENCES}

1. Kim YJ, Kim SJ, Min K, Kim HY, Kim HJ, Lee YK, et al. Multiple myeloma with myelomatous pleural effusion: a case report and review of the literature. Acta Haematol 2008;120(2):108-11.

2. Cho SY, Lim G, Oh SH, Lee HJ, Suh JT, Lee J, et al. Primary Plasma Cell Leukemia Associated with $\mathrm{t}(6 ; 14)(\mathrm{p} 21 ; \mathrm{q} 32)$ and IGH Rearrangement: A Case Study and Review of the Literature. Ann Clin Lab Sci 2011;41(3):277-81.

3. Kushwaha RA, Verma SK, Mehra S, Prasad R. Pulmonary and nodal multiple myeloma with a pleural effusion mimicking bronchogenic carcinoma. J Cancer Res Ther 2009;5(4):297-9.

4. Yochum TR, Rowe LJ. Tumors and Tumorlike Processes; Essentials of Skeletal Radiology. Baltimore: Williams \& Wilkins 1996:1004-13.

5. Carnesale PG. Malignant Bone Tumors; Campbell's Operative Orthopaedics. St.Louis: Mosby-Year Book Inc 1998:726-7.

6. Colonna A, Gualco G, Bacchi CE, Leite MA, Rocco $\mathrm{M}$, DeMaglio G, et al. Plasma cell myeloma presenting with diffuse pleural involvement: a hitherto unreported pattern of a new mesothelioma mimicker. Ann Diagn Pathol 2010;14(1):30-5.

7. Ghoshal AG, Sarkar S, Majumder A, Chakrabarti S. Unilateral massive pleural effusion: a presentation of unsuspected multiple myeloma. Indian J Hematol Blood Transfus 2010;26(2):62-4.

8. Riccardi A, Gobbi PG, Ucci G, Bertoloni D, Luoni R, Rutigliano L, et al. Changing clinical presentation of multiple myeloma. Eur J Cancer 1991;27(11):1401-5.

9. Nakazato T, Suzuki K, Mihara A, Sanada Y, Kakimoto T. Refractory plasmablastic type myeloma with multiple extramedullary plasmacytomas and massive myelomatous effusion: remarkable response with a combination of thalidomide and dexamethasone. Intern Med 2009;48(20):1827-32.

10. Goździuk K, Kedra M, Rybojad P, Sagan D. A rare case of solitary plasmacytoma mimicking a primary lung tumor. Ann Thorac Surg 2009;87(4):25-6. 